\title{
REKONSTRUKSI PEMBELAJARAN BAHASA ARAB DI PONDOK PESANTREN ASSUNNIYYAH JEMBER
}

\author{
Abdul Haris \\ Institut Agama Islam Negeri Jember, Indonesia \\ E-mail: abdulharis.albidayah3b@gmail.com
}

\begin{abstract}
This article attempts to unravel the failure of Arabic learning in formal education institutions and tries to offer alternative solutions. The failure of formal education institutions in learning Arabic is mostly due to the lack of clarity in the vision of the policy makers on the position and significance of Arabic materials. This is reflected in the policy regarding the frequency of face-to-face learning, qualifications of teaching staff, preparation of textbooks, and the position of Arabic language materials which are still not included in the category of national examination materials. The success of Assunniyyah Islamic Boarding School in Kencong Jember in learning Arabic is because they are able to present bi'ah 'Arabiyah (Arabic milieu) in the pesantren, even though they use ta'sir as one of their approaches. Formal education institutions are less successful, or even fail in learning Arabic because they fail to present bi'ah 'Arabiyah in their neighborhood. There are many points that need to be addressed in the context of designing Arabic learning in the formal education environment, both related to the creation of the environment, teacher qualifications and standardization of textbooks as learning resources, or related to the position of Arabic as material that adequately determines student graduation.
\end{abstract}

Keywords: Arabic milieu; teachers; pesantren.

\section{Pendahuluan}

Dalam kajian keislaman, bahasa Arab memiliki peran dan signifikansi yang cukup tinggi. Hal ini karena sumber utama dari ajaran Islam, yaitu al-Qur'ān dan Sunnah keduanya tertulis dengan menggunakan bahasa Arab, demikian juga dengan referensi-referensi yang mengupas tentang sisi ajaran Islam dari berbagai aspek dan dimensinya, mayoritas tertulis dengan menggunakan bahasa Arab. 
Menyadari tentang realitas ini, maka Kementerian Agama menetapkan materi bahasa Arab sebagai materi wajib yang harus dipelajari oleh peserta didik dari tingkat madrasah Ibtidaiyah, Tsanawiyah, Aliyah sampai perguruan tinggi yang ada di bawah naungan Kementerian Agama. ${ }^{1}$

Meskipun materi bahasa Arab wajib dipelajari oleh peserta didik di lembaga pendidikan formal di lingkungan kementerian Agama dari tingkat madrasah Ibtidaiyah sampai perguruan tinggi, akan tetapi hasil yang dicapai sampai saat ini terasa masih memprihatinkan. ${ }^{2}$ Dengan asumsi bahwa materi bahasa Arab mulai diajarkan pada saat peserta didik duduk di bangku kelas empat, maka pembelajaran bahasa Arab di lingkungan pendidikan formal dilakukan selama minimal sembilan tahun; sebuah masa pembelajaran yang cukup panjang yang apabila dikelola dengan benar dan maksimal pasti akan mampu meningkatkan kualitas kemampuan bahasa Arab para peserta didik. Dengan fasilitas, metodologi, dan strategi pembelajaran yang selalu di-update, seharusnya pembelajaran bahasa Arab di lembaga pendidikan formal di bawah naungan Kementerian Agama lebih sukses dibandingkan dengan pembelajaran bahasa Arab di lembaga pendidikan pesantren yang fasilitas, metodologi, dan strategi pembelajaran yang dimilikinya masih bersifat konvensional dan "hanya" ala kadarnya."

\footnotetext{
${ }^{1}$ Signifikansi bahasa Arab bagi kaum Muslim juga dapat disimpulkan dari penegasan al-Qur'ān. Kata “arabiyyan” disebutkan sebanyak sepuluh kali di dalam al-Qur’ān, yaitu dalam Q.S. al-Shu'arā’ [26]: 195, Q.S. al-Naḥl [16]: 103, Q.S. Yūsuf [12]: 2, Q.S. al-Ra'd [13]: 37, Q.S. Țāha [20]: 113, Q.S. al-Zumar [39]: 28, Q.S. Fușṣilat [41]: 3, Q.S. al-Shūrā [42]: 7, Q.S. al-Zuḥruf [43]: 3 dan Q.S. al-Aḥqāf [46]: 12. Di samping al-Qur'ān, dalam al-Ḥadīth juga menegaskan pentingnya bahasa Arab. Dalam sebuah hadīth yang diriwayatkan oleh al-Ḥākim dan perawi yang lain, Nabi Muhammad menegaskan:

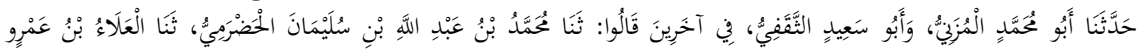

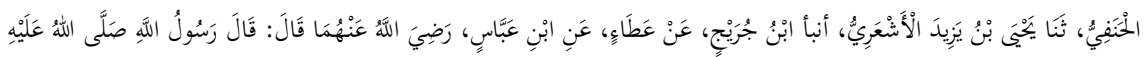

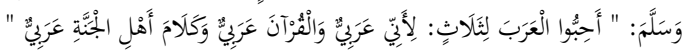

Abū 'Abd Allah al-Ḥākim al-Naysābūrī, al-Mustadrak 'alā al-Ṣậị̣ayn, Vol. 4 (Beirut: Dār al-Kutub al-'Ilmīyah, 1990), 97.

2 Bandingkan dengan tulisan Aziz Fahrurrozi, "Pembelajaran Bahasa Arab: Problematika dan Solusinya", Arabiyat: Jurnal Pendidikan Bahasa Arab dan Kebahasaaraban, Vol. 1, No. 2 (2014), 161.

3 Tentang ragam strategi pembelajaran bahasa Arab, baca Erta Mahyudin, "Model Pembelajaran Diskoveri sebagai Strategi Pembelajaran Bahasa Arab", Arabiyat: Jurnal Pendidikan Babasa Arab dan Kebahasaaraban, Vol. 1, No. 2 (2014), 198. 
Artikel ini mengupas tentang eksistensi Pondok Pesantren Assunniyah dalam mengembangkan pembelajaran bahasa Arab yang cukup berhasil meningkatkan kemampuan santri dalam berbicara bahasa Arab dengan mengembangkan model pembelajaran istimā', kalām, qirä'ah atau kitābah. ${ }^{4}$

\section{Belajar dari Pondok Pesantren Assunniyyah Kencong Jember}

Sampai saat ini pesantren merupakan lembaga yang dianggap sukses dalam membekali dan mengantarkan para santri untuk sampai pada tingkatan keterampilan tertentu dalam bidang bahasa Arab. Lembaga pendidikan yang terkenal dengan kesederhanaannya ini secara konsisten berusaha menghadirkan karakter bahasa (Baca keterpaksaan dan kebiasaan) di lingkungan mereka dalam pembelajaran bahasa Arab, baik dalam arti aktif maupun pasif. Hal ini tercermin dari kebijakan, program, dan kurikulum yang diterapkan oleh lembaga pendidikan pondok pesantren untuk para santrinya. Salah satu pesantren yang memiliki kebijakan, program, dan kurikulum sebagaimana dimaksud adalah Pesantren Assunniyyah.

Pesantren Assunniyyah berada di wilayah Kabupaten Jember, tepatnya di kecamatan Kencong. Pesantren yang memiliki visi utama mencetak para santrinya untuk mampu menjadi kader penerus dan pewaris para nabi ini memiliki konsentrasi yang cukup kuat dalam bidang mahärat al-qiräah. Keberhasilan pesantren yang didirikan oleh $\mathrm{KH}$. Djauhari Zawawi ini dalam rangka mengantarkan para santrinya pada tingkat kemampuan membaca dan memahami kitab tercermin dari prestasi yang diraih oleh para santrinya, baik di tingkat kabupaten, provinsi, atau di tingkat nasional. ${ }^{5}$

Pondok Pesantren Assunniyyah mewajibkan para santrinya untuk menetap dan bermukim di asrama pondok pesantren. Kebijakan semacam ini menjadikan para santri selalu berada dalam lingkungan yang kondusif ${ }^{6}$ untuk pembelajaran bahasa, dan terpantau serta terikat

\footnotetext{
${ }^{4}$ Keterampilan bahasa atau mahärat al-lughah pada umumnya diklasifikasikan menjadi empat, yaitu keterampilan mendengan (mahärat al-istimā'), keterampilan berbicara (mahärat al-kaläm), keterampilan membaca (mahärat al-qiräăab) dan keterampilan menulis (mahärat al-kitābah). Lebih lanjut lihat Ahmad Fuad Ulyan, al-Mahärat alLughawìyah (Riyad: Dār al-Salām, 1992), 23.

5 Anwar Syaddad (Ustaz Pembina Persiapan Lomba Pondok Pesantren Assunniyyah Kencong Jember), Wawancara, Jember 25 Februari 2017.

6 Lingkungan merupakan faktor penentu dalam pembelajaran bahasa. Berhasil tidaknya pembelajaran bahasa sangat tergantung pada sejauh mana seorang penentu
} 
pada aturan yang ditetapkan oleh pondok pesantren full time dua puluh empat jam dalam satu hari satu malam. Tidak hanya itu, pesantren juga seringkali membuat kebijakan tentang area atau batas wilayah yang tidak boleh dilampau oleh para santrinya. ${ }^{7} \mathrm{Hal}$ ini menjadikan para santri dapat terhindar dan terjaga dari pengaruh nagatif yang muncul dari lingkungan luar pesantren. Kebijakan sebagaimana di atas diberlakukan secara ketat oleh pondok pesantren terhadap para santrinya dan pesantren menyiapkan ta' ì $^{\prime}$ yang ketat terhadap para santri yang melanggar aturan yang telah ditetapkan. ${ }^{8}$

Kebijakan karantina yang diterapkan di Pesantren Assunniyyah dan di-back-up dengan ta' $2 i^{9}$ yang ketat sebagaimana di atas, menjadikan para santri terpaksa melakukan adaptasi dan pada akhirnya terbiasa melaksanakan program dan rutinitas kegiatan yang telah ditetapkan oleh Pesantren Assunniyyah. Hal ini sama dengan "orang asing" yang masuk dalam komunitas masyarakat tertentu yang terpaksa dan tidak ada pilihan lain bagi yang bersangkutan kecuali melakukan adaptasi dengan lingkungan barunya, baik dari sisi sikap,

kebijakan menghadirkan lingkungan bahasa. Lingkungan bahasa yang baik mampu memaksa para peserta didik untuk ikut-ikutan berbahasa dan pada akhirnya terbiasa untuk berbahasa. Tentang signifikansi lingkungan dalam pembentukan bahasa, Ahmad Fuad Ulyan berpendapat:

ان اللغة مكتسبة يكتسبها الفرد من البيئة التي ينشأ فيها بعد ولادته فمهما كانت جنسية الطفل المولود يمكنه ان يكتسب لغة البيئة

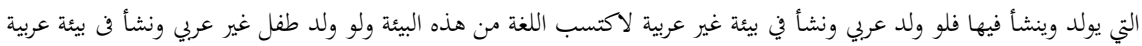

$$
\text { لاكتسب اللغة العربية من البيئة التي نشأ فيها. }
$$

Baca Ulyan, al-Mahārat, 23.

7 Ahmad Zaini (Ustaz Pondok Pesantren Assunniyyah Kencong Jember), Wawancara, Jember 23 Februari 2017.

${ }^{8}$ Ibid.

9 Legalitas ta'zîr untuk memaksa peserta didik membiasakan hal-hal yang baik, sehingga capaian pembelajaran dapat dimaksimalkan di dalam Islam dapat disimpulkan dari pembelajaran tentang salat. Di dalam Islam perintah salat oleh orang tua kepada anaknya dilakukan pada saat anak berusia tujuh tahun dan Islam merekomendasikan untuk memukul anak dengan pukulan yang tidak menyakitkan pada saat anak meninggalkan salat, sedangkan ia sudah berusia sepuluh tahun. Hal ini sebagaimana yang ditegaskan di dalam ḥadīth Nabi Muhammad:

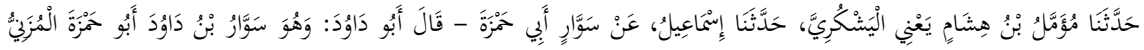

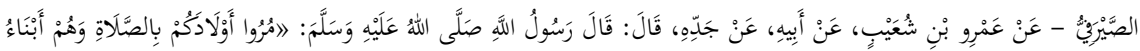

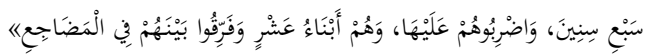

Lebih lanjut lihat: Abū Dāwud al-Sijistānī, Sunan Abì Dāwnd (Beirut: al-Maktabah al'Așrīyah, t.th.), I, 133. 
bahasa atau yang lain. "Orang asing" ini lambat laun tapi pasti akan terbiasa dan mampu bersikap serta berkomunikasi dengan komunitas yang ada di lingkungan barunya secara baik. Demikian juga halnya yang terjadi di pondok pesantren Assunniyyah.

Dalam konteks pesantren Assunniyyah, santri asal Madura yang pada awalnya sama sekali buta terhadap "bahasa resmi" yang digunakan pondok pesantren dalam metode penerjemahan kitab kuning, ${ }^{10}$ yaitu bahasa Jawa-lambat laun tapi pasti-akan terbiasa dan pada akhirnya akan mampu memahami dengan baik bahasa jawa ini, sehingga dalam tataran selanjutnya yang bersangkutan dapat mengikuti pengajian kitab kuning yang diselenggarakan oleh pondok pesantren dengan baik. Hal ini disebabkan karena tidak ada pilihan lain bagi yang bersangkutan kecuali terpaksa beradaptasi dengan bahasa resmi yang dipakai oleh pondok pesantren dalam menyampaikan materi pelajaran. Hal yang sama juga terjadi dalam konteks pesantren modern Gontor. Santri yang pada awalnya sama sekali tidak mengenal bahasa Arab, setelah menetap beberapa lama di pesantren Gontor yang bersangkutan akan mengenal dan bahkan pada akhirnya memiliki kemampuan untuk berkomunikasi secara aktif dengan menggunakan bahasa Arab. Hal ini karena pondok pesantren Gontor berhasil memaksa para santri untuk selalu berbahasa Arab serta memberikan sanksi yang tegas bagi mereka yang melanggar. Kebijakan seperti inilah yang harus diupayakan hadir dalam konteks pembelajaran bahasa Arab di lingkungan lembaga pendidikan formal.

Tatap muka pembelajaran di lingkungan Pesantren Assunniyyah dapat dikatakan tak terbatas. Di samping ada tatap muka pembelajaran formal yang wajib diikuti oleh semua santri pada waktu pagi hari, Pesantren Assunniyyah juga menawarkan program pembelajaran sunah dalam rangka memfasilitasi para santri untuk mengejar ketertinggalan atau mendalami materi pelajaran tertentu,

10 Metode pembelajaran kitab kuning yang umum dipakai di kalangan pondok pesantren adalah metode qawäid terjemah. Metode ini secara ketat memperhatikan sighat dan kedudukan i'räb sebuah kata dalam penerjemahan kitab kuning dengan cara memberikan simbol-simbol khusus untuk kedudukan i'räb tertentu. Kedudukan mubtada' biasa diberi simbol dengan “utaw”', sedangkan kedudukan khabar biasa diberi simbol denga "ikeu". Kedudukan fä ‘il atau naib al-fä íl biasa diberi simbol dengan "sopo" atau "opo", sementara maf"ūl bib diberi simbol dengan "ing" dan seterusnya. Terlepas dari pro-kontra model penerjemahan dengan menggunakan simbol-simbol makna jawa ini, yang jelas metode ini banyak berjasa dalam rangka mengantarkan para santri untuk sampai pada tingkat keterampilan bahasa tertentu, khususnya dalam bidang membaca teks Arab. 
sehingga hampir secara keseluruhan waktu yang dimiliki oleh para santri dapat digunakan secara maksimal untuk kepentingan belajar atau mendalami kitab kuning. Hal ini sangat mungkin untuk dilakukan karena kebetulan para ustaz atau tutor bertempat tinggal di asrama yang sama dengan para santri. ${ }^{11}$

Sikap sam'an wa tá'atan yang menjadi watak pesantren menjadikan para santri tidak mudah mengeluh sehingga pondok pesantren sangat untuk menambah porsi belajar dalam rangka memastikan tingkat penguasaan materi yang telah diajarkan. Dalam konteks inilah kegiatan takeär, shäwir, dan babth al-masäil sangat mudah untuk dilaksanakan secara istiqamah di lingkungan pesantren, termasuk di lingkungan Pesantren Assunniyyah Kencong Jember.

Kegiatan takeār, shäwir, dan baḥth al-masäil berbeda dengan kegiatan belajar mengajar formal yang secara reguler dilaksanakan di kelas dan didampingi oleh seorang ustaz sebagai aktor utama. Kegiatan tersebut yang wajib diikuti oleh semua santri ini dilaksanakan lebih santai dan rileks karena kegiatan ini pada umumnya tidak didampingi oleh ustaz. Kegiatan ini diatur dan dikelola sendiri oleh para santri yang menjadi anggota kelas tertentu sehingga para santri dapat dengan leluasa melakukan perdebatan atau mengungkapkan ketidakpahaman tanpa harus merasa malu atau yang lain. Posisi ustaz dalam kegiatan ini tidak lebih hanya sekadar fasilitator, pengawas atau pemantau. ${ }^{12}$

Pondok Pesantren Assunniyyah juga mendesain kurikulumnya secara khusus. Semua materi yang diajarkan, baik yang terkait dengan fiqh, ushul fiqh, tafsir, sejarah dan lain-lain menggunakan buku ajar yang standar dan tertulis dengan menggunakan bahasa Arab. Hal ini makin menjadikan para santri terpaksa dan terbiasa berinteraksi dengan teks Arab, meskipun tidak sedang belajar bahasa Arab. Para santri yang akan mempelajari fiqh, sejak tahun pertama di pesantren akan dikenalkan dengan kitab al-Mabädi' al-Fiqhìjah, Safinat al-Najāh, Sullam al-Tanfiq, Fath al-Qarï, dan seterusnya yang kesemuanya tertulis dengan menggunakan bahasa Arab. Pun juga demikian yang terjadi ketika mereka akan mempejari akidah, akhlak, sejarah atau yang lain. Mereka pasti mempelajarinya dengan menggunakan fasilitas kitab yang tertulis dengan menggunakan bahasa Arab. Kebijakan semacam

\footnotetext{
${ }^{11}$ Agus H. Baha'uddin Zuhair (Mudì 'Ām Pondok Pesantren Assunniyyah Kencong Jember), Wawancara, Jember 26 Februari 2017.

12 Ibid.
} 
ini pada akhirnya menjadikan para santri merasa dekat dengan bahasa Arab dan bahkan mampu meningkatkan insting kebahasaan mereka, sehingga mereka merasa nyaman dan familiar ketika berinteraksi dengan teks Arab. ${ }^{13}$

Untuk memperjelas kebijakan pondok pesantren sebagaimana di atas, di bawah ini ditampilkan jadwal pelajaran untuk Madrasah Tsanawiyah dan Aliyah Pondok Pesantren Assunniyyah Kencong Jember:

Tabel 1.1

Materi Pelajaran PP. Assunniyyah Kencong Jember

\begin{tabular}{|c|c|c|}
\hline No & Kelas & Materi \\
\hline 1 & Kelas I Tsanawiyah & $\begin{array}{l}\text { al-Qur'ān, Sullam al-Tawfīq, Käshifat al-Sajā, } \\
\text { Mukhtasar Jiddan, dan Kaylānī }\end{array}$ \\
\hline 2 & Kelas II Tsanawiyah & $\begin{array}{l}\text { al-Qur'ān, Fatḥ Rabb al-Bariyah, dan Hall al- } \\
\text { Ma'qūd }\end{array}$ \\
\hline 3 & Kelas III Tsanawiyah & $\begin{array}{l}\text { al-Qur'ān, Jawharat al-Tawhịd, Tafsìr Jalälayn } \\
\text { dan Tafsir al-Munir. }\end{array}$ \\
\hline 4 & Kelas I Aliyah & $\begin{array}{l}\text { Mafähim Yajibu an Tusaḅhaḥ, Tafsìr Jalälayn } \\
\text { dan Tafsir al-Munir. }\end{array}$ \\
\hline 5 & Kelas II Aliyah & $\begin{array}{l}\text { Mafähim Yajibu an Tusaḥhạ̣, Tafsìr Jalälayn } \\
\text { dan Tafsir al-Munir. }\end{array}$ \\
\hline 6 & Kelas III Aliyah & $\begin{array}{l}\text { Mafähim Yajibu an Tusaḥhạ̣, Tafsìr Jalälayn } \\
\text { dan Tafsir al-Munir. }\end{array}$ \\
\hline 7 & Kelas I Takhassus & $\begin{array}{l}\text { Ibyà' 'Ulüm al-Dìn, Sharh al-Hikam, Tafsir al- } \\
\text { Munī, Risālat al-Mu'äwanah, dan Minhäj al- } \\
\text { 'Ābidīn. }\end{array}$ \\
\hline 8 & Kelas II Takhașsuṣ & $\begin{array}{l}\text { Ibyà' 'Ulüm al-Dìn, Sharh al-Hikam, Tafsir al- } \\
\text { Munìr, Risälat al-Mu'äwanah, dan Minhäj al- } \\
\text { 'Ábidin. }\end{array}$ \\
\hline
\end{tabular}

Sumber: Dokumen tentang Profil Pondok Pesantren Assunniyyah, 2012.

Dari contoh jadwal pelajaran yang diambil dari pondok pesantren Assunniyyah Kencong Jember di atas dapat diketahui bahwa buku ajar yang ditetapkan sebagai sarana untuk menguasai disiplin keilmuan tertentu secara keseluruhan mulai dari tingkat pertama sampai tingkat yang terakhir semuanya merujuk pada kitab tertentu dan tertulis dengan menggunakan bahasa Arab. Tugas seorang ustaz adalah membacakan dan menerjemahkan serta menguraikan isi, maksud dan kandungan kitab tersebut. Seorang ustaz tidak diperkenankan

13 Ahmad Muhammad Nasih (Guru Tugas dari Pondok Pesantren Assunniyyah Kencong Jember), Wawancara, Jember 17 Juli 2017. 
menyampaikan materi pelajaran dengan menggunakan buku ajar yang lain, lebih-lebih yang berbahasa Indonesia. ${ }^{14}$ Fenomena semacam ini dalam konteks pembelajaran bahasa Arab dapat membantu para santri dalam melakukan percepatan untuk menguasai materi bahasa Arab, karena frekuensi interaksi santri dengan teks bahasa Arab berlangsung terus menerus secara berkesinambungan dan tidak dibatasi oleh jumlah SKS. Hal inilah yang menjadikan insting kebahasaan dan koleksi mufradāt yang dimiliki oleh para santri terbilang cukup tinggi.

Belajar tuntas bukanlah merupakan wacana teoretis yang hanya dibincang dan didiskusikan di kalangan Pesantren Assunniyyah. Ia benar-benar nyata dipraktikkan dan diimplementasikan dalam setiap kegiatan belajar mengajar. Fath al-Qarīb, Fatḥ al-Muiñ dan Fatḥ alWabhäb merupakan kitab fiqh yang diajarkan di dunia Pesantren Assunniyyah. Kitab-kitab ini dibaca, dikaji dan didiskusikan secara tuntas mulai dari bab yang pertama sampai yang terakhir sesuai dengan tingkatan kelas yang sudah ditentukan. Jurümiyah, Mutammimah, Imritī dan Alfìah merupakan kitab-kitab naḥw yang diajarkan di Pesantren Assunniyyah. Kitab-kitab ini dibaca, dikaji dan didiskusikan secara tuntas mulai dari bab yang pertama sampai yang terakhir sesuai dengan tingkatan kelas yang sudah ditentukan. ${ }^{15}$ Bahkan untuk materi naḥw Pondok Pesantren Assunniyyah menerapkan kewajiban hafalan terhadap para santrinya dan memberikan sanksi tertentu terhadap santri yang kurang memenuhi target hafalan yang telah ditentukan. Demikian juga halnya dengan kitab dalam bidang akidah, akhlak dan lain-lain, semuanya diajarkan secara tuntas dari awal sampai akhir kepada para santrinya. Penuntasan semua materi yang telah ditetapkan dalam konteks Pesantren Assunniyyah sangat mungkin untuk dilakukan karena di samping waktu yang tersedia cukup banyak, sehingga intensitas dan frekuensi pembelajaran dapat dimaksimalkan, para santri juga tidak disibukkan dengan materi-materi lain yang tidak ada kaitannya dengan tafaqquh fi al-din. Kebijakan belajar tuntas semacam ini, ketika dikaitkan dengan pembelajaran bahasa Arab mampu menjadikan para santri memiliki koleksi mufradät yang lebih komprehensif. Dalam bidang fiqh misalnya, mereka akan memiliki koleksi mufradāt yang terkait dengan bab ibādah, mu'ämalah, munākahạ̄h

14 Ahmad Faiz Kurniawan (Pengurus Pondok Pesantren Assunniyyah Kencong Jember), Wawancara, Jember 23 April 2017.

15 Ahmad Muhammad Nasih (Guru Tugas Pondok Pesantren Assunniyyah Kencong Jember), Wawancara, Jember 17 Juli 2017. 
dan bab jināyah. Demikian juga halnya dengan bidang naḥw, para santri akan mengenal konsep dan memiliki mufradāt tentang bab kalimah, i'räb, marfu' 'àt al-asmà', mansübät al-asmà', majrürät al-asmä', dan lain-lain; sebuah capaian pembelajaran yang sulit dilakukan dalam konteks lembaga pendidikan formal.

Untuk dapat mengikuti ujian, Pesantren Assunniyyah mempersyaratkan agar kitab yang dimiliki santri yang menjadi buku ajar dan sudah dibacakan oleh ustaznya harus selesai dimaknai secara lengkap. Kitab dengan makna lengkap ini harus disetor kepada ustaz pembimbingnya untuk diteliti kelengkapan maknanya. Proses inilah yang dikenal dengan istilah taftish. Santri yang mengumpulkan kitab dengan makna lengkap dianggap memenuhi persyaratan untuk mengikuti ujian, sedangkan santri yang tidak mengumpulkan kitab dengan makna lengkap dianggap tidak memenuhi persyaratan untuk mengikuti ujian. Persyaratan semacam ini menjadikan para santri terpaksa harus nembel (melengkapi) dengan menambah jam belajar atau waktu ekstra ketika kenyataannya pemaknaan kitab yang dimilikinya kurang lengkap atau kurang memenuhi standar untuk dijadikan sebagai persyaratan ujian di pondok pesantren. Kebijakan semacam ini akan mampu memaksa para santri untuk mengenal dan bahkan menghafal secara lebih detail kosa kata yang sangat dibutuhkan dalam mempelajari kitab kuning. ${ }^{16}$

Tentang bagaimana menentukan tenaga pengajar, Pesantren Assunniyyah juga memiliki karakteristik yang khas. Sebagai sebuah lembaga yang tidak ada kaitannya dengan lembaga pendidikan formal dan tidak terikat dengan berbagai aturan yang ditetapkan oleh Kementerian Agama tentang syarat-syarat yang harus dipenuhi oleh seorang guru, paradigma yang digunakan untuk menentukan tenaga pengajar adalah paradigma kelayakan, bukan kewenangan secara formal. Secara formal seseorang dianggap memiliki kewenangan untuk mengajar apabila ia memiliki ijazah atau sertifikat kependidikan tertentu, meskipun aspek kognitif, afektif dan psikomotoriknya jauh dari kata layak. Paradigma kelayakan yang diterapkan oleh pesantren ini menjadikan ijazah dan sertifikat kependidikan formal tidak terlalu penting. Penguasaan materi yang diajarkan, sikap dan keterampilam mengajar secara real yang dimiliki oleh para calon guru dianggap lebih

16 Ahmad Zaini (Ustaz Pondok Pesantren Assunniyyah Kencong Jember), Wawancara, Jember 21 Januari 2017. 
penting dibandingkan dengan hanya secarik ijazah dan sertifikat. ${ }^{17}$ Dalam konteks Pesantren Assunniyyah, seorang sarjana lulusan program studi bahasa Arab tidak boleh serta merta berkeinginan untuk menjadi tenaga pengajar di lingkungan pondok pesantren. Bahkan ketika yang bersangkutan berkeinginan untuk bergabung dan nyantri di Pondok Pesantren Assunniyyah, maka bisa jadi yang bersangkutan harus memulai pembelajaran dari tingkat dasar atau Ibtidaiyah ketika realitasnya kemampuan yang dimiliki masih berkategori tingkat Ibtidaiyah. Kebijakan tentang kualifikasi tenaga pengajar yang diterapkan secara ketat oleh Pondok Pesantren Assunniyyah dapat memastikan para santri dibina, dibimbing dan dididik oleh sosok ustaz yang tepat yang memiliki kompetensi keilmuan yang mumpuni. ${ }^{18}$

Uraian tentang potret pembelajaran bahasa Arab di Pondok Pesantren Assunniyyah dari berbagai dimensinya sebagaimana di atas menjadikan capaian pembelajaran bahasa Arab dapat dimaksimalkan, sehingga keterampilan bahasa, baik yang terkait dengan istimā', kaläm, qiräah dan kitäbah yang menjadi tujuan pondok pesantren dapat disaksikan secara nyata dalam diri para santri.

17 Salah satu kitab wajib yang dijadikan panduan oleh kalangan pesantren dalam melaksanakan proses belajar mengajar adalah kitab Ta'lim al-Muta'allim karya Shaykh al-Zarnujī. Tentang bagaimana cara memilih tenaga pengajar, al-Zarnujī mengatakan:

$$
\text { واما اختيار الاستاذ فينغى ان يختار الاعلم والاورع والاسن }
$$

Lebih lanjut lihat: Burhān al-Islām al-Zarnujī, Ta'lìm al-Muta'allim Ṭariq al-Ta'allum (Khartoum: al-Dār al-Sūdānīyah li al-Kutub, 2004), 19.

${ }_{18}$ Hal yang senada juga pernah disampaikan oleh Muhbib Abdul Wahab bahwa keberadaan guru yang profesional sangat penting dalam proses pembelajaran mengingat peran dan fungsinya sebagai intelektual transformatif. Bahkan ia menambahkan bahwa perlahan terjadi pergeseran "kaidah edukasi", dimana posisi seorang tenaga pengajar jauh lebih signifikan dibandingkan dengan metode itu sendiri. Kaidah lama yang berbunyi al-tariqah ahamm min al-mäddah (metode itu lebih penting daripada materi itu sendiri) mulai digeser oleh kaidah baru yang berbunyi: almudarris al-mu'abhal ahamm wa akthar ta'thiran fi ta'lim al-lughah al''Arabiyah min altariqah (guru yang professional itu lebih penting dan lebih berpengaruh pada pembelajaran bahasa Arab daripada metode). Lebih lanjut lihat: Muhbib Abdul Wahab, "Pembelajaran Bahasa Arab di Era Posmetode", Arabiyat: Jurnal Pendidikan Bahasa Arab dan Kebahasaaraban, Vol. 2, No. 1 (2015), 67. 


\section{Realitas di Lembaga Pendidikan Formal}

Realitas pembelajaran bahasa Arab di lingkungan pendidikan formal berbeda jauh dengan pembelajaran bahasa Arab di lingkungan pondok pesantren. Dari sisi ini nampaknya dapat dibaca dan diukur tingkat keseriusan Kementerian Agama dalam rangka mengupayakan peserta didik untuk sampai pada tingkat kemampuan "memadai" dalam bidang bahasa Arab.

Mata pelajaran bahasa Arab di lembaga pendidikan formal pada umumnya maksimal diajarkan dua kali dalam satu minggu. ${ }^{19}$ Dengan kebijakan seperti ini, lembaga pendidikan formal sulit untuk dapat mengahadirkan lingkungan berbahasa yang dapat menunjang pencapaian tujuan pembelajaran bahasa Arab. Peserta didik tidak akan merasa "terpaksa" dan pada akhirnya "terbiasa" terhadap bahasa Arab. Intensitas dan frekuensi pembelajaran yang cukup rendah ditambah jumlah rombongan belajar yang tidak ideal dalam setiap kelasnya dengan tingkat heteroginitas yang tinggi dalam hal minat belajar bahasa Arab makin memperparah tingkat keberhasilan pembelajaran bahasa Arab di lembaga pendidikan formal. Para peserta didik di lembaga pendidikan formal pada umumnya hanya "menguasai" materi pelajaran bahasa Arab yang terakhir. Sedangkan materi pelajaran sebelumnya pada umumnya sudah dilupakan. Siswa kelas tiga MTs misalnya, pada umumnya sudah melupakan materi pelajaran bahasa Arab kelas satu dan kelas dua, demikian juga yang terjadi pada siswa di tingkat Aliyah, sehingga fenomena yang terjadi menunjukkan mahasiswa baru yang pada waktu "SMP-nya" bersekolah di madrasah Tsanawiyah dan pada waktu "SMA-nya" bersekolah di madrasah Aliyah pada umumnya merasa "asing" dan "buta" terhadap bahasa Arab.

Penggunaan buku ajar yang berbahasa Indonesia untuk materi pelajaran agama, seperti fiqh, al-Qur'ān-Hadīth, Akidah-Akhlak dan lain-lain berdampak serius pada instink kebahasaan para peserta didik. Instink kebahasaan yang sangat dibutuhkan dalam pembelajaran bahasa Arab hanya dapat dicapai dengan cara meningkatkan intensitas

\footnotetext{
${ }^{19}$ Bandingkan dengan hasil temuan yang pernah disampaikan oleh Aliyatin Nafisah dalam hasil penelitiannya yang berjudul "Model dan Problematika Pembelajaran bahasa Arab Di SMA Islam Keling Jepara" dimana bahasa Arab yang merupakan Mapel Muatan Lokal memiliki jumlah jam pelajaran sebanyak 2 jam/minggu sehingga dalam setiap bulannya ada 4 kali pertemuan. Lebih lanjut lihat: Aliyatin Nafisah, "Model dan Problematika Pembelajaran Bahasa Arab di SMA Islam Keling Jepara”, Cendekia, Vol. 10, No. 1 (Juni 2012), 140.
} 
dan frekuensi interaksi peserta didik dengan materi kebahasaan, baik secara langsung pada saat pembelajaran materi pelajaran bahasa Arab, ataupun tidak langsung pada saat mengkaji kitab fiqh, tafsir, akidah dan lain-lain yang tertulis dengan menggunakan bahasa Arab. Di samping itu, penggunaan buku ajar yang berbahasa Indonesia menutup peluang peserta didik untuk dapat mengkoleksi mufradät atau perbendaharaan kata yang sebanyak-banyak dalam bidang kajian keagamaan yang beraneka ragam. Hal ini penting karena unsur mufradät dalam belajar bahasa merupakan kunci untuk menguasai sebuah bahasa. Semakin banyak mufradät dikuasai dan dihafal, semakin besar pula peluang seseorang untuk menguasai bahasa dimaksud, demikian pula sebaliknya.

Untuk memperoleh gambaran tentang hal di atas, di bawah ini ditampilkan kurikulum yang ditawarkan oleh Kementerian Agama untuk madrasah Tsanawiyah dan Madrasah Aliyah:

Tabel 1.2

Jadwal Pelajaran Lembaga Pendidikan Formal ${ }^{20}$

\begin{tabular}{|c|c|c|c|c|c|c|}
\hline \multirow[t]{2}{*}{ Komponen } & \multicolumn{3}{|c|}{$\begin{array}{c}\text { Alokasi Waktu KTSP } \\
2008\end{array}$} & \multicolumn{3}{|c|}{$\begin{array}{c}\text { Alokasi Waktu } \\
\text { KTSP KMA 2007 }\end{array}$} \\
\hline & VII & VIII & IX & VII & VIII & IX \\
\hline \multicolumn{7}{|l|}{ Mata Pelajaran } \\
\hline \multicolumn{7}{|l|}{$\begin{array}{l}\text { Pendidikan Agama } \\
\text { Islam }\end{array}$} \\
\hline Al-Qur’ān Hadis & 2 & 2 & 2 & 2 & 2 & 2 \\
\hline Akidah Akhlak & 2 & 2 & 2 & 2 & 2 & 2 \\
\hline Fiqh & 2 & 2 & 2 & 2 & 2 & 2 \\
\hline $\begin{array}{l}\text { Sejarah Kebudayaan } \\
\text { Islam }\end{array}$ & 2 & 2 & 2 & 2 & 2 & 2 \\
\hline $\begin{array}{l}\text { Pendidikan } \\
\text { kewarganegaraan }\end{array}$ & 2 & 2 & 2 & 2 & 2 & 2 \\
\hline Bahasa Indonesia & 4 & 4 & 4 & 4 & 4 & 4 \\
\hline Bahasa Arab & 2 & 2 & 2 & 3 & 3 & 3 \\
\hline Bahasa Inggris & 4 & 4 & 4 & 4 & 4 & 4 \\
\hline Matematika & 4 & 4 & 4 & 4 & 4 & 4 \\
\hline $\begin{array}{l}\text { Ilmu pengetahuan } \\
\text { Alam }\end{array}$ & 4 & 4 & 4 & 4 & 4 & 4 \\
\hline Ilmu Pengetahuan & 4 & 4 & 4 & 4 & 4 & 4 \\
\hline
\end{tabular}

${ }^{20}$ http://simpatika.kemenag.go.id/statik/pdf/STANDAR_KURIKULUM_MADR ASAH_SIMPATIKA_2016_versi1.0.pdf (diakses tanggal 23-06-2017) 


\begin{tabular}{|l|l|l|l|l|l|l|}
\hline Sosial & & & & & & \\
\hline Seni Budaya & 2 & 2 & 2 & 2 & 2 & 2 \\
\hline $\begin{array}{l}\text { Pendidikan Jasmani, } \\
\text { Olahraga, dan } \\
\text { Kebudayaan }\end{array}$ & 2 & 2 & 2 & 2 & 2 & 2 \\
\hline Keterampilan/TIK & 2 & 2 & 2 & 2 & 2 & 2 \\
\hline & & & & & & \\
\hline Muatan Lokal *) & 2 & 2 & 2 & 2 & 2 & 2 \\
\hline $\begin{array}{l}\text { Pengembangan Diri } \\
* *\end{array}$ & 2 & 2 & 2 & 2 & 2 & 2 \\
\hline Jumlah Asal & 40 & 40 & 40 & 40 & 40 & 40 \\
\hline Jumlah Terbaru & & & & 41 & 41 & 41 \\
\hline
\end{tabular}

*) Muatan Lokal terhitung sebagai Mata Pelajaran

**) Pengembangan Diri tidak terhitung sebagai Mata Pelajaran

Tabel 1.3

Struktur Kurikulum Jenjang MA Tingkat 11 dan 12 Program Bahasa

\begin{tabular}{|l|c|c|c|c|c|c|c|c|}
\hline \multirow{2}{*}{ Komponen } & \multicolumn{3}{|c|}{ Alokasi Waktu KTSP 2008 } & \multicolumn{3}{c|}{ Alokasi Waktu KTSP } \\
& \multicolumn{2}{|c|}{ Kelas XI } & \multicolumn{2}{c|}{ Kelas XII } & \multicolumn{2}{c|}{ Kelas XI } & \multicolumn{2}{c|}{ Kelas XII } \\
\cline { 2 - 10 } & $\begin{array}{c}\text { Smt } \\
\mathbf{1}\end{array}$ & $\begin{array}{c}\text { Smt } \\
\mathbf{2}\end{array}$ & $\begin{array}{c}\text { Smt } \\
\mathbf{1}\end{array}$ & $\begin{array}{c}\text { Smt } \\
\mathbf{2}\end{array}$ & $\begin{array}{c}\text { Sm } \\
\text { t 1 }\end{array}$ & $\begin{array}{c}\text { Smt } \\
\mathbf{2}\end{array}$ & $\begin{array}{c}\text { Sm } \\
\text { t1 }\end{array}$ & $\begin{array}{c}\text { Sm } \\
\text { t 2 }\end{array}$ \\
\hline Mata Pelajaran & & & & & & & & \\
\hline & & & & & & & & \\
\hline $\begin{array}{l}\text { Pendidikan } \\
\text { Agama Islam }\end{array}$ & & & & & & & & \\
\hline Al-Qur'ān Hadis & 2 & 2 & 2 & 2 & 2 & 2 & 2 & 2 \\
\hline Akidah Akhlak & 2 & 2 & - & - & 2 & 2 & 2 & 2 \\
\hline Fiqh & 2 & 2 & 2 & 2 & 2 & 2 & 2 & 2 \\
\hline $\begin{array}{l}\text { Sejarah } \\
\text { Kebudayaan } \\
\text { Islam }\end{array}$ & - & - & 2 & 2 & 2 & 2 & 2 & 2 \\
\hline $\begin{array}{l}\text { Pendidikan } \\
\text { kewarganegaraan }\end{array}$ & 2 & 2 & 2 & 2 & 2 & 2 & 2 & 2 \\
\hline Bahasa Indonesia & 5 & 5 & 5 & 5 & 5 & 5 & 5 & 5 \\
\hline Bahasa Arab & 2 & 2 & 2 & 2 & 2 & 2 & 2 & 2 \\
\hline Bahasa Inggris & 5 & 5 & 5 & 5 & 5 & 5 & 5 & 5 \\
\hline Bahasa Asing *) & 4 & 4 & 4 & 4 & 4 & 4 & 4 & 4 \\
\hline Matematika & 3 & 3 & 3 & 3 & 3 & 3 & 3 & 3 \\
\hline Sastra Indonesia & 4 & 4 & 4 & 4 & 4 & 4 & 4 & 4 \\
\hline
\end{tabular}




\begin{tabular}{|l|c|c|c|c|c|c|c|c|}
\hline Antropologi & 2 & 2 & 2 & 2 & 2 & 2 & 2 & 2 \\
\hline Sejarah & 2 & 2 & 2 & 2 & 2 & 2 & 2 & 2 \\
\hline Seni budaya & 2 & 2 & 2 & 2 & 2 & 2 & 2 & 2 \\
\hline $\begin{array}{l}\text { Pendidikan } \\
\text { Jasmani, } \\
\begin{array}{l}\text { Olahraga, dan } \\
\text { Kebudayaan }\end{array}\end{array}$ & 2 & 2 & 2 & 2 & 2 & 2 & 2 & 2 \\
\hline $\begin{array}{l}\text { Teknologi } \\
\text { Informasi dan } \\
\text { Komunikasi }\end{array}$ & 2 & 2 & 2 & 2 & 2 & 2 & 2 & 2 \\
\hline Keterampilan & 2 & 2 & 2 & 2 & 2 & 2 & 2 & 2 \\
\hline & 2 & 2 & 2 & 2 & 2 & 2 & 2 & 2 \\
\hline $\begin{array}{l}\text { Muatan Lokal } \\
\text { *) }\end{array}$ & 2 & 2 & 2 & 2 & 2 & 2 & 2 & 2 \\
\hline & 45 & 45 & 45 & 45 & 45 & 45 & 45 & 45 \\
\hline $\begin{array}{l}\text { Pengembangan } \\
\text { Diri **) }\end{array}$ & & & & 47 & 47 & 47 & 47 \\
\hline
\end{tabular}

*) Muatan Lokal terhitung sebagai Mata Pelajaran

**) Pengembangan Diri tidak terhitung sebagai Mata Pelajaran.

Dari kurikulum di atas menjadi jelas bahwa yang menjadi misi utama dari Kementerian Agama adalah menyampaikan materi tertentu dalam disiplin keilmuan yang bermacam-macam. Kementerian Agama tidak menetapkan kitab tertentu sebagai buku ajar yang wajib dijadikan sebagai pegangan. Pada umumnya buku ajar yang dipakai sebagai fasilitas dan sarana pembelajaran tertulis dengan menggunakan bahasa Indonesia. Realitas semacam ini menjadikan frekuensi interaksi para peserta didik dengan bahasa Arab sangat terbatas. Para peserta didik tidak belajar bahasa Arab kecuali pada saat jam pelajaran bahasa Arab. Hal inilah yang pada akhirnya menjadikan instink kebahasaan dan koleksi mufradāt para peserta didik cukup rendah.

Paradigma penentuan tenaga pengajar dalam konteks lembaga pendidikan formal dalam implementasinya lebih banyak berorientasi pada kewenangan, bukan kelayakan. ${ }^{21}$ Dalam rekrutmen guru atau

${ }^{21}$ Sebenarnya dari sisi teori semua pakar dan praktisi, baik dari lingkungan lembaga pendidikan formal atau pesantren sepakat bahwa kelayakan atau kompetensi menjadi kata kunci yang tidak dapat ditawar dan harus dipenuhi oleh calon tenaga pengajar bahasa Arab, meskipun dari sisi implementasinya sikap kedua lembaga ini 
dosen dalam bidang bahasa Arab misalnya, persyaratan yang tidak dapat ditawar dan wajib dipenuhi oleh para pelamar dalam mengajukan lamaran adalah kelengkapan ijazah Strata Satu (S-1) atau Strata Dua (S-2) dalam bidang bahasa Arab. Seseorang yang mampu memenuhi kelengkapan ijazah dianggap memenuhi persyaratan administrasi dan berhak untuk mengikuti tahapan seleksi berikutnya, sedangkan seseorang yang tidak dapat memenuhi kelengkapan ijazah dianggap tidak memenuhi kelengkapan persyaratan administrasi, sehingga yang bersangkutan dianggap gugur dan tidak berhak untuk mengikuti tahapan berikutnya. Paradigma semacam ini menyebabkan potensi "salah pilih" dalam penentuan tenaga pengajar sangat besar, lebih-lebih dalam konteks kekinian dimana formalitas kesarjanaan dalam bidang kajian keagamaan, termasuk di dalamnya adalah bahasa Arab seringkali tidak berbanding lurus dengan tingkat kualitas keilmuan yang dimiliki. ${ }^{22}$

Ketika realitasnya demikian, maka pertanyaan besar yang kemudian mengemuka adalah: "mungkinkah sosok tenaga pengajar yang dianggap memiliki kewenangan untuk mengajar, akan tetapi dari sisi keilmuan dinilai kurang memiliki kompetensi dan kelayakan akan mampu menjadi tenaga pengajar yang dapat mengantarkan para peserta didik untuk sampai pada tujuan pembelajaran yang sudah ditetapkan?". Teori dasar yang sulit untuk dibantah adalah "tidak mungkin orang yang tidak memahami dengan baik tentang materi tertentu dalam bidang apapapun mampu memberikan pemahaman tentang materi tersebut kepada orang lain, karena proses

berbeda. Tentang kualifikasi kompetensi yang ideal yang harus dimiliki oleh seorang tenaga pengajar bahasa Arab, Uril Bahruddin menegaskan:

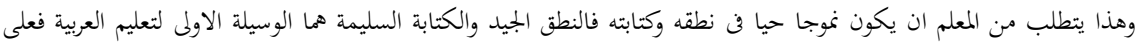

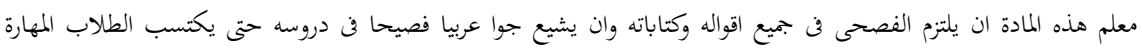

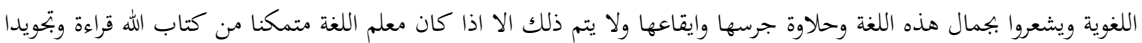

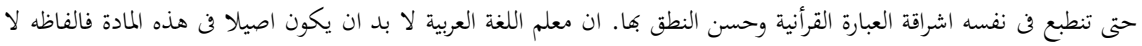

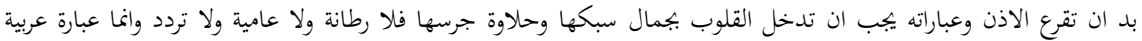

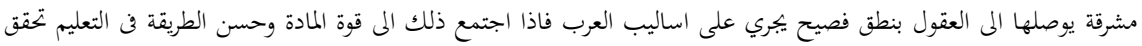

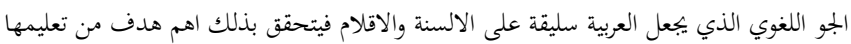

Lihat Bahruddin, Mahārat, 51.

${ }^{22}$ Salah satu tulisan menarik yang dapat dibaca terkait dengan problematika tenaga pengajar bahasa Arab di Indonesia dapat dibaca dalam: Asep M. Tamam, "Program Penyiapan dan Pembinaan Guru Bahasa Arab Profesional di Indonesia", Arabiyat: Jurnal Pendidikan Bahasa Arab dan Kebahasaaraban, Vol. 1, No. 1 (2014), 49. 
memahamkan (al-tafhim) pasti berangkat dari paham (al-fahm) terlebih dahulu. Hal ini dalam ungkapan bahasa Arab terkenal dengan anna faqida al-shay' là yu'tit. ${ }^{23}$

Hal serius lain yang terjadi dalam pembelajaran bahasa Arab di lembaga pendidikan formal adalah mengenai ketuntasan belajar. Masalah ketuntasan belajar sebenarnya cukup ditekankan di lembaga pendidikan formal, akan tetapi implementasi dan aplikasinya jauh dari kata ideal. Seandainya diasumsikan bahwa untuk dapat berbahasa Arab, baik aktif maupun pasif seseorang minimal membutuhkan dua unsur atau komponen bahasa, yaitu kaidah-kaidah (nahw-sarf) dan mufradät, maka dapat dibuktikan bahwa pengajaran kaidah dan mufradāt serta sejauh mana upaya maksimal yang dilakukan oleh lembaga untuk memantau dan memonitor tingkat penguasaan peserta didik dalam dua bidang yang cukup menentukan ini terasa sangat rendah dan kurang tuntas.

Untuk dapat mengetahui dan memahami tentang perubahan kata (sighat) di dalam bahasa Arab, seseorang perlu mempelajari ilmu sarf. ${ }^{24}$ Dalam konteks yang sederhana seseorang dapat dianggap menguasai ilmu sarf ketika ia terampil men-tasriff, baik istilähì, maupun lughawi,

${ }^{23}$ Bahruddin, Mahārat, 51.

${ }^{24}$ Keterampilan men-tasriff fi ill, baik tasrif istilahi, maupun tasrif lughawi dalam konteks lembaga pendidikan formal tidak dilatihkan secara intensif, bahkan dari data yang ada berupa buku pelajaran yang dijadikan sebagai buku ajar yang dipelajari di madrasah Tsanawiyah dan Aliyah sama sekali tidak disinggung tentang bagaimana cara men-tasrif fi íl. Seorang peserta didik tidak mungkin mampu melakukan identifikasi untuk menentukan jenis kata, apakah termasuk dalam kategori masdar, ism fä́il, ism maf'ül, ism zamān dan ism älat apabila yang bersangkutan tidak dilatih secara intensif ilmu sarf ini. Kebijakan yang berbeda diambil oleh lembaga pondok pesantren. Lembaga yang dipimpin oleh seorang kyai ini bahkan pada umumnya menuntut semua santrinya hafal buku al-amtsilat al-tasrifiyah. Signifikansi ilmu sarf dapat dilihat dari penegasan para ahli. Menurut para ahli sarf adalah umm al-ulum (induk ilmu), sebagaimana yang dijelaskan di dalam kitab:

الصرف أم العلوم أي أصلها ومبدؤها لأنما يبدأ منها العلوم، يقال للفاتحة أم القرآن وأم الكتاب؛ لأها أصل القرآن منها يبدأ القرآن

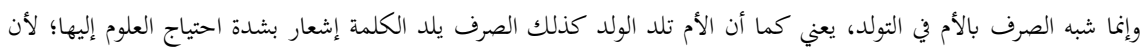
الأم لا يكاد يستغني الولد عنها

Lebih lanjut lihat: Syamsuddin Ahmad, Syarban 'ala Mirah al-Arwah fi Tlm al-Sarf (Mesir: Shirkah Maktabah wa Maṭba'ah Muṣtafā al-Bābi al-Halabī wa Awlādih, 1959), 3. 
mampu mengidentifikasi dan memahami jenis kata (sighat), dan memahami dengan baik tentang fawäid al-ma'nă. ${ }^{25}$

Tiga unsur ini apabila dijadikan sebagai barometer untuk ketuntasan belajar dalam bidang ilmu sarf yang merupakan unsur yang tak terpisahkan dalam pembejaran bahasa Arab, maka pembelajaran bahasa Arab di lembaga pendidikan formal kurang tuntas.

Demikian juga halnya dengan ilmu nabw. Ilmu ini adalah ilmu yang tidak dapat dilepaskan dalam proses pembelajaran bahasa Arab. Ilmu ini dapat pula dijadikan sebagai barometer dalam melihat ketuntasan belajar bahasa Arab di lembaga pendidikan formal. Secara umum dapat dijelaskan bahwa materi pelajaran yang ditawarkan di didalam ilmu naḥw adalah sebagai berikut:

1. Materi tentang kalimah (kata) yang pada umumnya dibagi menjadi tiga, yaitu: kalimah fi íl, ism dan hurüf.

2. Materi tentang i'rāb yang pada umumnya dibagi menjadi tiga, yaitu: marfü'ät al-asmä', majrürät al-asmä', dan mansübät al-asmä'.

3. Materi tentang jumlah yang pada umumnya dibagi menjadi dua, yaitu jumlah yang memiliki kedudukan i'räb (al-jumal al-latì lahà mahall min al-iräab) dan jumlah yang tidak memiliki kedudukan íräb (al-jumal al-latì là mahall lahā min al-íräb).

Tiga unsur ini apabila dijadikan sebagai indikator ketuntasan belajar dalam bidang ilmu naḥw yang merupakan unsur yang tak terpisahkan dalam pembejaran bahasa Arab, maka pembelajaran bahasa Arab di lembaga pendidikan formal Jauh dari kata tuntas. Hal yang sama juga terjadi dalam konteks pembelajaran mufradät.

Materi tentang ilmu naḥw tidak diajarkan secara tuntas dapat diketahui dari buku pelajaran bahasa Arab yang dijadikan sebagai buku ajar di madrasah Tsanawiyah dan madrasah Aliyah. Dalam buku ajar tersebut, baik di tingkat Tsanawiyah ataupun Aliyah, tidak ada pembahasan secara khusus yang mengurai tentang bab tamyiz, maf ${ }^{\gamma} \bar{l} l$ mutlaq, maf'ül li ajlih, maf'ül fih, maf'ül ma'ah, munāda, ism là al-latì li nafy

\footnotetext{
${ }^{25}$ Ficil mujarrad ketika dirubah menjadi fi il mazid, apakah mazid bi harf, bi harfayn atau bi thalathat abruf, maka secara arti akan mengalami perubahan. Fi il mujarrad k-r-m memiliki arti mulia. Ficil ini ketika dirubah menjadi mazìd dengan diikutkan pada wazn af'ala akan menjadi akrama. Setelah menjadi akrama artinya bukan "mulia", akan tetapi "memuliakan". Perubahan fi'il dengan diikutkan pada wazan-wazan tertentu yang berdampak pada perubahan arti inilah yang kemudian terkenal dengan sebuatan fawäid al-ma'nā. Lebih lanjut lihat: Muhammad Ma'ṣūm b. 'Alī, al-Amthilah al-Tașrifizyah (Surabaya: Maṭba'ah Sālim Nabhān, t.th.), 14-37.
} 
al-jins dan materi yang lain yang secara nyata dapat ditemukan di dalam teks Arab. ${ }^{26}$ Karena demikian, peserta didik yang "murni" mendapatkan ilmu bahasa Arab dari lembaga pendidikan formal di bawah naungan Kementerian Agama tidak akan mampu menganalisis teks arab dan pasti akan mengalami kebingungan ketika yang bersangkutan berhadapan dengan teks arab yang susunan íräb-nya

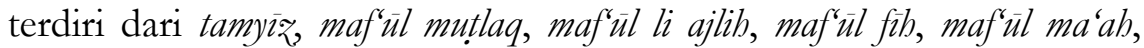
munāda dan ism là al-latì li nafy al-jins, karena materi ini sama sekali tidak pernah mereka kenal. ${ }^{27}$

Di samping materi pelajaran tidak ditawarkan secara tuntas, sistematika penyusunan materi juga kurang memperhatikan logika berfikir ilmu nahbw yang lurus. Harus diakui bahwa di dalam ilmu naḥw terdapat dua klasifikasi materi yang apabila diabaikan akan berdampak pada kekacauan berpikir para peserta didik. Dua klasifikasi materi dimaksud adalah materi prasyarat dan materi inti atau pokok. Materi prasyarat adalah materi yang menjadi prasyarat dan harus dikuasai terlebih dahulu oleh para peserta didik sebelum yang bersangkutan belajar materi inti atau materi pokok. Materi tentang fä́il adalah materi inti atau materi pokok. Seorang peserta didik tidak memungkinkan

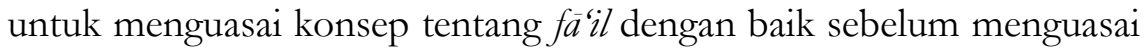
materi prasyarat tentang fíil ma'lüm dan fíil majhül karena ism yang dibaca rafa' yang jatuh setelah kalimah fi'il dapat berkedudukan sebagai

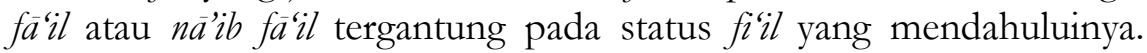
Ketika kenyataannya fícil yang mendahuluinya berupa fi' il ma'lìm, maka ism tersebut berkedudukan sebagai fä $\hat{i} l$, akan tetapi apabila fí̀ yang mendahuluinya berupa fíil majbül, maka ism tersebut berkedudukan sebagai näib fä îl.

Materi tentang maf'ül bib sulit untuk dipahami dengan baik oleh para peserta didik ketika konsep tentang fícil läzim-fícil muta'addi belum tuntas diajarkan. Pun juga demikian, konsep tentang na'at-man'üt sulit

\footnotetext{
26 Data tentang ketidak-ketuntasan materi bahasa Arab dapat dilihat dalam tabel materi pelajaran bahasa Arab untuk madrasah Tsanawiyah dan madrasah Aliyah yang akan diurai lebih lanjut dalam pembahasan tentang sistematika.

27 Ketuntasan pembelajaran ilmu nahw dalam konteks pembelajaran bahasa Arab menjadi penting untuk diperhatikan karena tanpa ilmu nahw teks bahasa Arab tidak mungkin untuk dipahami. Hal ini sesuai dengan penegasan al-Imrithi yang menyatakan:

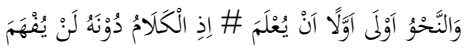
Lebih lanjut lihat: al-Bājurī, Fatḥ Rabb al-Barìyah 'alā al-Durrah al-Babīyah: Sharḅ 'Imrị̂ī (Surabaya: Maktabah Imaratullah, t.th), 5.
} 
untuk dikuasai dengan baik oleh para peserta didik ketika konsep tentang ism sifat, ism mufrad-tathniyah-jama', mudhakkar-muannath dan konsep tentang ma'rifah-nakirah belum tuntas diajarkan karena antara na'at dan man'üt harus berkesesuaian dari sisi mufrad-tathniyah-jama', mudhakekar-muannath, dan ma'rifah-nakirah-nya. Hampir semua materi inti apakah yang termasuk dalam kategori marfü'at al-asmā, mansübät alasmä', dan majrürät al-asmä' memiliki prasyarat. Realitas semacam ini nampaknya kurang diperhatikan dalam rangka menyusun sistematika materi pelajaran bahasa Arab di lembaga pendidikan formal.

Untuk mendapatkan gambaran yang lebih konkret tentang sistematika materi pelajaran bahasa Arab di lembaga pendidikan formal, di bawah ini ditampilkan urutan materi pelajaran bahasa Arab mulai dari tingkat Tsanawiyah sampai tingkat Aliyah.

\section{Tabel 1.4}

Materi Pelajaran Bahasa Arab Madrasah Tsanawiyah

\begin{tabular}{|c|c|c|}
\hline Kelas VII ${ }^{28}$ & Kelas VIII ${ }^{29}$ & Kelas IX ${ }^{30}$ \\
\hline $\begin{array}{l}\text { Mubtada' dan Khabar } \\
\text { Ism Damìr } \\
\text { Ism Ishärah } \\
\text { Adawät al-Jarr } \\
\text { Damir Muttasil Mufrad } \\
\text { 'Adad } \\
\text { Khabar Muqaddam dan } \\
\text { Mubtada' Muakhbkhar } \\
\text { Mubtada' Khabar } \\
\text { (Mubtada' Mufrad dan } \\
\text { Khabar berupa Fi'il } \\
\text { Mudäri') }\end{array}$ & 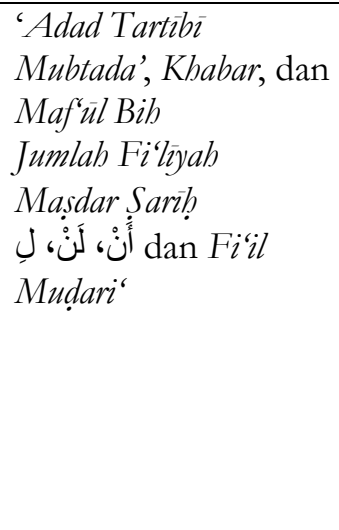 & 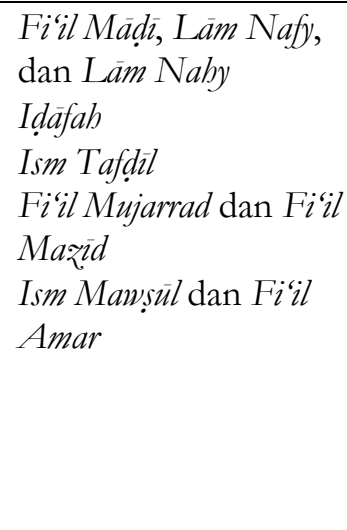 \\
\hline
\end{tabular}

Sistematika materi pelajaran bahasa Arab untuk madrasah Tsanawiyah sebagaimana yang tergambar di dalam tabel di atas sangat

28 Darsono dan T. Ibrahim, Fasih Berbahasa Arab untuk Kelas VII Madrasah Tsanawiyah (Solo: PT Tiga Serangkai, 2014).

29 Darsono dan T. Ibrahim, Fasib Berbahasa Arab Untuk Kelas VIII Madrasah Tsanawiyah (Solo: PT Tiga Serangkai, 2015).

${ }^{30}$ Darsono dan T. Ibrahim, Fasih Berbahasa Arab Untuk Kelas IX Madrasah Tsanawiyah (Solo: PT Tiga Serangkai, 2013). 
sulit untuk diterima sebagai sistematika yang logis dan rasional yang diharapkan mampu membantu para peserta didik untuk lebih mudah dalam rangka memahami dan menguasai materi pelajaran bahasa Arab, karena sistematika di atas sama sekali tidak memperhatikan klasifikasi materi inti dan materi prasyarat.

Sistematika yang ditawarkan oleh Kementerian Agama di atas bermasalah dapat dijelaskan sebagai berikut: materi pelajaran yang pertama kali diajarkan di kelas satu MTs adalah tentang mubtada'khabar. Materi ini tidak mungkin dapat diajarkan dengan baik sebelum para peserta didik mengenal atau menguasai dengan baik tentang materi prasyaratnya, yaitu materi tentang ism ma'rifah dan ism nakirah yang ternyata sama sekali tidak dikenalkan, baik pada saat peseta didik duduk di bangku kelas satu, dua atau kelas tiga madrasah Tsanawiyah. Materi tentang ism ma'rifah dan ism nakirah ini disebut sebagai materi prasyarat karena mubtada' tidak memungkinkan kecuali terbuat dari ism ma'rifah atau ism nakirah mufidah. ${ }^{31}$ Akan terjadi lompatan berpikir yang berdampak pada kebingungan peserta didik dalam menangkap materi pelajaran tentang mubtada'-khabar ketika konsep tentang ism ma'rifah dan ism nakirah sama sekali belum dikenal.

Materi tentang maf'ül bih diajarkan pada saat peserta didik duduk di bangku kelas dua madrasah Tsanawiyah. Uraian dan penjelasan tentang konsep maf'ul bih akan dapat dipahami dengan baik, ketika peserta didik sudah menguasai konsep fícil läæim dan fíil muta'addí. Karena materi tentang fílil muta 'addi merupakan materi prasyarat untuk masuk pada materi tentang maf'ül bih, maka akan terjadi lompatan berpikir yang berdampak pada kebingungan peserta didik dalam menangkap dan memahami materi maf'ül bih ketika yang bersangkutan sama sekali belum mengenal materi tentang fícil muta' addì yang menjadi materi prasyarat. ${ }^{32}$ Demikian juga halnya dengan materi-materi yang

31 Mubtada harus terbuat dari ism ma'rifah dapat dilihat dari Ibn Mālik dalam Alfiyahnya yang berbunyi:

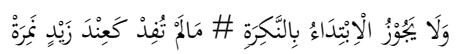

Lebih lanjut lihat: 'Abd Allah b. 'Aqil, Sharḥ Ibn 'Aqül, Vol. 1 (Beirut: Dār al-Fikr, t.th.), 215.

32 Materi tentang fi'il muta'addi merupakan materi prasyarat untuk materi tentang maf'ül bih dapat disimpulkan dari penjelasan Ibn 'Aqīl ketika menguraikan tentang konsep fíil muta'addì dan fícil lä̧̃im. Ia menegaskan:

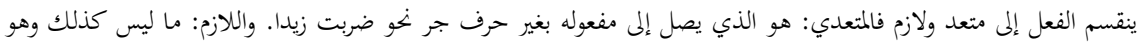

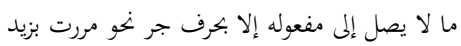


lain yang ternyata sangat sulit dicari basis rasionalisasinya karena kurang memperhatikan klasifikasi materi menjadi materi prasyarat dan materi inti.

Analisis dan uraian sebagaimana di atas mungkin dapat dijadikan sebagai jawaban mengapa para peserta didik sama sekali kelihatan "buta" terhadap materi bahasa Arab pada saat yang bersangkutan memasuki jenjang pendidikan yang selanjutnya.

Sementara materi pelajaran bahasa Arab yang ditawarkan untuk madrasah Aliyah adalah sebagai berikut:

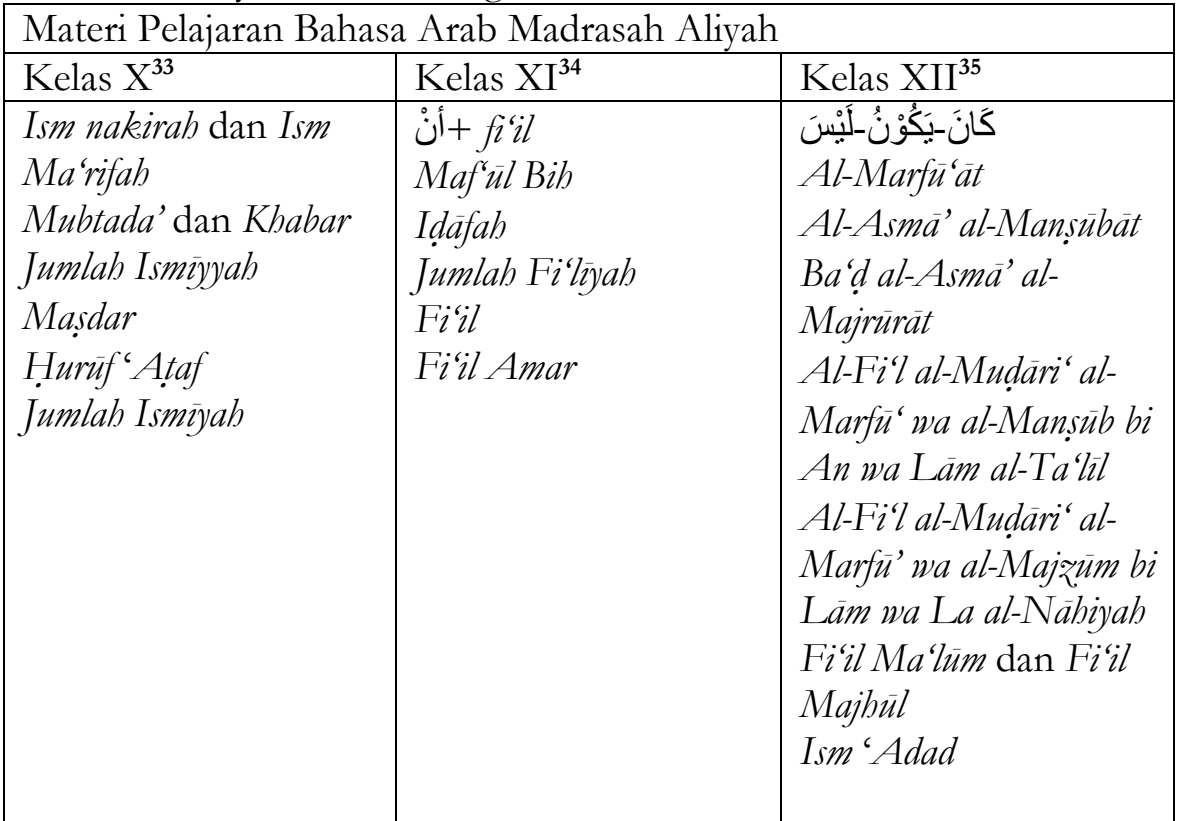

Jumlah fi'liyah yang pada umumnya diterjemahkan dengan jumlah yang minimal tersusun dari fíil dan fä́il ditawarkan pada saat pertengahan kelas dua Aliyah. Seharusnya materi pelajaran ini

Baca Ibn 'Aqil, Sharḥ Ibn 'Aqül 'alà Alfíyat ibn Mālik, Vol. 2 (Kairo: Dar al-Turāth, 1980), 145.

33 Kementerian Agama Republik Indonesia, Durus al-Lughah al-'Arabiyyah: Buku Siswa Bahasa Arab Pendekatan Saintifik. Kurikulum 2013 Kelas X (Jakarta: Kementerian Agama Republik Indonesia, 2014).

${ }^{34}$ Kementerian Agama Republik Indonesia, Durüs al-Lughah al-'Arabiyah: Buku Siswa Bahasa Arab Pendekatan Saintifik Kurikulum 2013 Kelas XI (Jakarta: Kementerian Agama Republik Indonesia, 2015).

35 Saepul Hidayat, Belajar Efektif Bahasa Arab Untuk Madrasah Aliyah Kelas XII (Jakarta Timur: PT Intermedia Ciptanusantara, t.th.). 
ditawarkan setelah materi tentang fíil ma'lium dan fi íl majbül karena fi ìl ma'lüm dan fíil majbül merupakan materi prasyarat untuk masuk pada pembahasan tentang jumlah fi'liyah. Apakah ism yang dibaca rafa' yang jatuh setelah fícil disebut sebagai fácil atau disebut sebagai náa'ib fásil tergantung status ficil yang ada. Ketika fi ill-nya termasuk dalam kategori fícil ma 'lüm, maka ism yang dibaca rafa' tersebut disebut sebagai $f_{a}^{-} i^{i} \bar{p}^{6}$, sedangkan apabila status ficilnya termasuk dalam kategori majbül, maka ism yang dibaca rafa' tersebut disebut sebagai nä 'ैib fä́ril. ${ }^{37}$ Dari sistematika sebagaimana yang digambarkan di dalam tabel di atas dapat diketahui bahwa materi tentang fi íl ma 'lüm dan fíil majbül baru ditawarkan pada saat kelas tiga akhir.

Berpikir sistematis merupakan kata kunci untuk keberhasilan pembelajaran bahasa Arab dan hal ini dapat dilakukan ketika materimateri yang diajarkan disusun dengan menggunakan sistematika yang logis dan rasional. Realitasnya materi pembelajaran bahasa Arab di madrasah Aliyah sebagaimana yang digambarkan dalam tabel di atas disusun dengan tidak memperhatikan sistematika yang logis dan rasional, sehingga yang terjadi bukan memberikan pemahaman yang utuh dan komprehensif tentang sebuah konsep materi tertentu dalam pembelajaran bahasa Arab kepada para peserta didik, akan tetapi justeru mengacaukan logika berpikir mereka. Inilah yang pada akhirnya menjadikan para peserta didik lulusan madrasah Aliyah kelihatan "buta" terhadap materi bahasa Arab pada saat mereka memasuki jenjang perguruan tinggi.

36 Ulama naḥw mendefinisikan fácil dengan:

كل اسم دلَّ على من فعَل الفعلَ أَو اتصف به وسُبق بفعل مبني للمعلوم أَو شبهه مثل: "قرأت الطالبة، ونام الطفلُ، وجاري حسنةٌ

Lebih lanjut Baca Sa`īd b. Muḥammad b. Aḥmad al-Afghānī, al-Mujì fi Qawāòid alLughah al-'Arabiyah (Beirut: Dār al-Fikr, 2003), 214.

Dari definisi ini dapat ditegaskan keterkaitan antara fíil ma lüm dengan fä ìl, sehingga dapat disimpulkan bahwa materi tentang fi'il ma'lum merupakan materi prasyarat untuk materi tentang fä íl.

${ }^{37}$ Muștafā al-Ghulayainī mendefinisikan nāìb al-fä́il dengan:

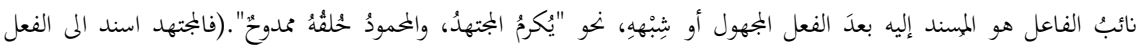

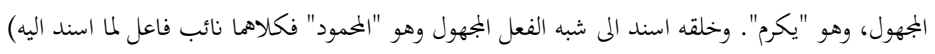

Lihat: Muḥammad b. Muḥammad Sālim al-Ghulayaynī, Jāmi‘ al-Durūs al-'Arabìyah, Vol. 2 (Beirut: al-Maktabah al-'Așrīyah, 1993), 246.

Dari uraian ini dapat ditegaskan keterkaitan antara fíil majhül dengan näìb al-fä́il, sehingga dapat disimpulkan bahwa materi tentang fíil majhül merupakan materi prasyarat untuk materi tentang nä̀ib al-fä îl. 


\section{Desain Pembelajaran Bahasa Arab}

Untuk mendesain pembelajaran bahasa Arab, hal penting yang harus ditegaskan terlebih dahulu adalah sejauh mana para penentu kebijakan menganggap bahasa Arab sebagai materi penting yang harus mendapatkan prioritas dan perhatian yang cukup serius, atau sejauh mana para penentu kebijakan memiliki visi yang jelas untuk menjadikan para peserta didik mampu menguasai, mengkaji dan bahkan pada akhirnya mampu menjadi ahli di bidang keagamaan yang sumber utama dan mayoritas referensinya tertulis dengan menggunakan bahasa Arab. Hal ini menjadi penting dalam konteks lembaga pendidikan formal karena kebijakan dari otoritas penentu kebijakan merupakan instruksi yang harus diikuti. ${ }^{38}$ Improviosasi dan kreativitas menjadi sangat terbatas dan kurang berarti ketika sejak awal ruang gerak dari para pengajar bahasa Arab tidak mendapatkan dukungan dan bahkan dibatasi oleh otoritas penentu kebijakan, baik kepala madrasah, maupun Kementerian Agama pusat.

Setelah menganggap penting dan memiliki visi yang jelas tentang bahasa Arab, seorang penentu kebijakan juga perlu memahami karakter bahasa yang sangat membutuhkan lingkungan bahasa (bïab 'Arabiyah), kualifikasi guru dan signifikansi sistematika materi bahasa Arab yang ditawarkan dalam buku ajar dalam rangka mengantarkan peserta didik untuk sampai pada keterampilan ideal dalam bidang bahasa Arab. Memang, lembaga pendidikan formal tidak mungkin meniru secara total kebijakan dan tradisi pembelajaran bahasa Arab yang dilakukan oleh kalangan pondok pesantren. Oleh sebab itu pendekatan yang harus dipergunakan dalam mendesain pembelajaran bahasa Arab adalah kaidah yang menyatakan mà là yudraku kullub là

38 Penguasa atau penentu kebijakan cukup berperan dalam mengarahkan sikap, perilaku dan kreativitas bawahan dan rakyatnya dapat disimpulkan dari uraian sebagai berikut:

واعلم أنّ للملك أمورا تخصّه يتميز بما عن السوقة، فمنها: أنه إذا أحبّ شيئا أحبه الناس، وإذا أبغض شيئا أبغضه الناس، وإذا لهج

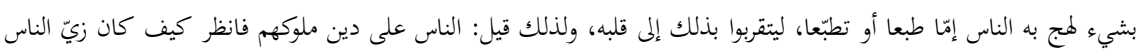

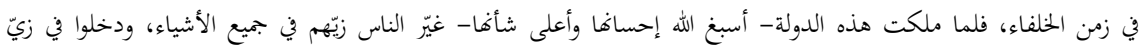

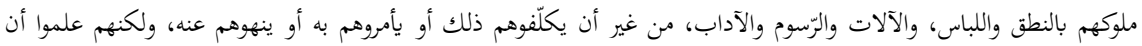

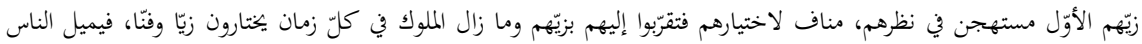

$$
\text { إليه ويلهجون به، وهذا من خواصّ الدولة وأسرار الملك. }
$$

Baca Ibn al-Ṭaqtuqī, al-Fakhr fì al-Adab al-Sultānìyah wa al-Duwal al-Islāmìyah (Beirut: Dār al-Qalam al-'Arabī, 1997), 32. 
yutrak kulluh (Sesuatu yang tidak dapat diperoleh secara keseluruhan tidak boleh ditinggal secara keseluruhan). ${ }^{39}$

Meskipun dalam konteks lembaga pendidikan formal tidak mungkin menyiapkan bi'ah 'Arabijah sebagaimana yang terdapat di pondok pesantren, hal penting yang harus dipahami sejak awal adalah bi'ah 'Arabiyah memiliki andil yang cukup dominan dalam rangka menjadikan peserta didik memiliki keterampilan bahasa yang sudah ditetapkan. Hampir tidak ditemukan peserta didik yang sukses mencapai tujuan pembelajaran bahasa Arab dididik dan dibina dalam sebuah lembaga pendidikan yang bi'ab 'Arabiyah-nya sangat lemah. Karena demikian, sebisa mungkin penentu kebijakan harus melakukan terobosan dan inovasi untuk dapat membentuk bìab 'Arabijah, meskipun dalam sekala dan area yang cukup terbatas dan minim. Penyiapan bi'ah 'Arabijah dalam konteks lembaga pendidikan formal dapat dilakukan dengan memanfaatkan dan memaksimalkan muatan lokal, misalnya dengan menambah frekuensi tatap muka jam pelajaran bahasa Arab atau mengisolasi program studi dan jurusan tertentu yang memiliki korelasi yang cukup signifikan dengan bahasa Arab. Dalam konteks madrasah, kebijakan kepala madrasah menetapkan jam pertama sebagai jam wajib untuk belajar bahasa Arab setiap hari, ${ }^{40}$ baik dalam konteks penguatan keterampilan istimā', kaläm, qirä'ah atau kitäbah untuk jurusan bahasa Arab atau keagamaan akan berdampak cukup signifikan dalam rangka meningkatkan keterampilan bahasa

${ }^{39}$ Kaidah yang menjelaskan tentang manusia harus melakukan apa yang mampu dilakukannnya dapat dilihat di dalam syarah ḥadīth:

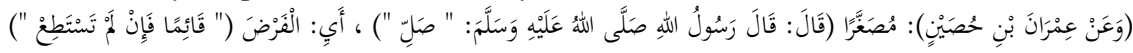

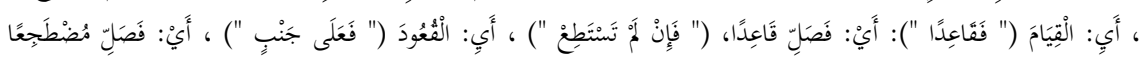

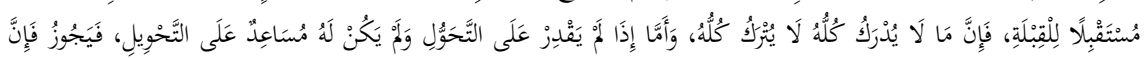

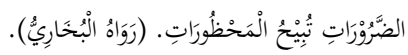

Baca Abū al-Ḥasan Nūr al-Dīn al-Mala al-Harawī al-Qari, Mirqat al-Mafätị̣: Sharḥ Mishkeāt al-Masābih, Vol. 3 (Beirut: Dār al-Fikr, 2002), 936.

40 Belajar bahasa apapun, frekuensi dan intensitas pembelajaran cukup menentukan tingkat kesusksesan pencapaian tujuannya. Maksudnya, semakin tinggi frekuensi dan intensitas pembelajaran bahasa, maka semakin tinggi tingkat kesuksesan pencapaian tujuannya, semakin rendah frekuensi dan intensitas pembelajaran bahasa, maka semakin rendah pula tingkat kesuksesan pencapaian tujuannya. Dengan tetap mempertahankan jumlah tatap muka maksimal dua kali dalam satu minggu sebagaimana kurikulum saat ini, lembaga pendidikan formal di bawah naungan Kementerian Agama selamanya tidak akan mampu mencetak peserta didik yang tangguh penguasaan bahasanya. 
Arab peserta didik, lebih-lebih tempat dan ruang kelas mereka diisolasi sebagaimana hal ini pernah dilakukan oleh Kementerian Agama pada Madrasah Aliyah Program Khusus (MAPK) pada saat Kementerian Agama dipimpin oleh Munawir Syadzali yang terbukti para alumni dan lulusannya mendapatkan apresiasi dan sukses dalam menjalani karir akademis sebagai ahli dan pakar di bidang keagamaan.

Meskipun peserta didik dalam konteks pembelajaran modern dianggap sebagai subyek pembelajaran, sementara guru atau tenaga pengajar tidak lebih hanya dianggap sebagai fasilitator dalam pembelajaran, akan tetapi peran, fungsi dan signifikansi guru tidak dapat diabaikan dalam rangka mengantarkan para peserta didik untuk sampai pada tujuan pembelajaran bahasa Arab. Guru yang mampu mengemban amanah seperti ini adalah guru yang berkualitas, karena fäqid al-shay' là yu'ți (orang yang tidak memiliki kompetensi tidak akan mampu memberikan kontribusi). Dalam konteks inilah penentu kebijakan harus memiliki pandangan yang ekstrem untuk tidak mengangkat guru bahasa Arab kecuali yang berkualitas. ${ }^{41}$

Guru yang berkualitas dalam konteks pembelajaran bahasa Arab bukan hanya guru yang menguasai materi bahasa Arab, akan tetapi juga memahami filosofi dan fungsi dari masing-masing materi bahasa Arab. Seandainya materi bahasa Arab berceceran dalam sebuah tempat, guru bahasa Arab yang berkualitas mampu menyusunnya kembali secara sistematis dan menempatkan kembali sesuai dengan peta konsep yang seharusnya. ${ }^{42}$ Guru bahasa Arab yang memahami

${ }^{41}$ Realitasnya guru yang mendapatkan SK sebagai tenaga pengajar bahasa Arab dapat diklasifikasikan menjadi dua, yaitu guru yang memiliki kualifikasi untuk mengajar bahasa Arab dan guru yang tidak memiliki kualifikasi untuk mengajar bahasa Arab. Untuk guru dengan kualifikasi yang terakhir ini, seorang kepala madrasah harus melakukan "klinik" secara serius. Seandainya kemampuannya tidak dapat diupgrade, maka kepala sekolah harus menggantinya dengan tenaga pengajar yang lain.

42 Tidak mudah untuk sampai pada tingkat dimana seorang guru mampu memahami filosofi dan fungsi masing-masing materi yang terdapat di dalam bahasa Arab. Dengan menggunakan proses yang alamiyah dibutuhkan ketekunan, perenungan dan pengalaman yang luar biasa untuk dapat sampai pada tingkatan kemampuan tersebut. Karena demikian, para penentu kebijakan harus memfasilitasi para guru bahasa Arab, utamanya yang masih pemula untuk dapat melakukan percepatan sehingga tidak hanya mampu menguasai materi bahasa arab, akan tetapi juga memahami filosofi dan fungsi dari masing-masing materi yang sudah dikuasainya. Hal ini dapat dilakukan dengan cara membangun kerja sama dengan para pakar dari perguruan tinggi, pesantren dan pihak-pihak terkait yang lain untuk dapat mendidik dan meng-upgrade kemampuan para guru dalam bidang bahasa Arab. 
filosofi dan fungsi dari masing-masing materi bahasa Arab akan mampu memetakan kaitan antara materi yang satu dengan materi yang lain, sehingga ia akan dapat menjadi fasilitator pembelajaran yang baik dan juga memiliki keahlian untuk menilai sebuah materi bahasa Arab, apakah termasuk materi yang sangat penting, penting atau tidak penting. Karena demikian, guru yang memiliki kualifikasi semacam ini dapat menjadi solusi dalam menghadapi keterbatasan waktu yang tersedia dan juga menjadi solusi ketika realitasnya buku ajar yang ditetapkan pemerintah kurang memenuhi standar sebagai buku ajar yang baik.

Dalam konteks pembelajaran bahasa Arab, hal penting yang menjadi tugas utama dari seorang guru bahasa Arab adalah membentuk struktur dan kerangka pikir yang sistematis dan komprehensif pada benak dan pemikiran peserta didik. Hal ini tidak memungkinkan dilakukan kecuali oleh guru yang sejak awal memiliki struktur dan kerangka pikir yang sistematis dan komprehensif. peserta didik yang memiliki struktur dan pola pikir yang sistematis dan komprehensif akan mampu "menikmati" pembelajaran bahasa Arab dan secara mandiri dan kreatif yang bersangkutan akan mampu mengembangkan keterampilan bahasa yang dimilikinya dengan menggunakan sumber belajar yang lain dan tanpa tergantung pada bantuan guru.

Buku ajar memiliki peran yang cukup strategis dalam rangka mengantarkan peserta didik untuk sampai pada tingkat keterampilan bahasa Arab yang sudah ditentukan. ${ }^{43}$ Hal ini karena dalam konteks lembaga pendidikan formal buku ajar merupakan satu-satunya sumber belajar dalam bentuk buku yang dimiliki oleh peserta didik dalam mempelajari bahasa Arab. Karena demikian, maka proses pembuatan buku ajar harus ditangani oleh tim yang memiliki kapasitas keilmuan yang cukup tinggi dalam bidang bahasa Arab. Sampai saat ini nampaknya kementerian agama kurang memiliki kepedulian yang cukup serius tentang masalah buku ajar bahasa Arab, sehingga buku yang beredar di "pasaran" bukan merupakan buku resmi yang dikeluarkan oleh kementerian agama, bahkan yang dipakai di banyak

43 Mengenai perbandingan buku ajar bahasa Arab yang digunakan di lembaga pendidikan formal, penelitian dari M. Syamsul Ma'arif dapat menjadi salah satu rujukan. Lihat: M. Syamsul Ma'arif, "Perbandingan Kualitas Buku Teks Bahasa Arab Tingkat Madrasah Tsanawiyah", Jurnal Pendidikan Islam, Vol. 4, No. 1 (Juni 2015), 209. 
lembaga pendidikan formal, baik tingkat Tsanawiyah atau Aliyah tidak lebih hanya sekadar Lembar Kerja Siswa (LKS). ${ }^{44}$

Keterlibatan banyak pakar dalam rangka penyusunan buku ajar menjadi penting karena perkembangan keterampilan yang diharapkan untuk masing-masing tingkatan peserta didik harus benar-benar tercermin dalam buku ajar, baik dari sisi perkembangan gramatika, mufradät atau keterampilan yang lain. dari sisi gramatika, buku ajar untuk tingkat Ibtidaiyah harus berbeda dengan buku ajar untuk tingkat Tsanawiyah atau Aliyah. Pun juga demikian halnya dengan perkembangan mufradāt. Yang jelas adalah buku ajar mulai dari tingkat Ibtidaiyah, Tsanawiyah dan Aliyah harus merupakan satu kesatuan yang utuh dan berkelanjutan dan ini dapat direalisasikan apabila penyusunan buku ajar dikoordinasi oleh satu badan yang dibentuk oleh kementerian agama dan tidak disusun oleh perorangan sebagaimana yang terjadi saat ini. Penggunaan buku ajar yang tidak standar merupakan kendala yang cukup serius dalam rangka pencapaian tujuan pembelajaran bahasa Arab, sehingga ketika kementerian agama belum mampu menyusun buku ajar yang standar, maka lebih baik menghimbau atau bahkan menginstruksikan lembaga pendidikan formal untuk menggunakan buku ajar yang sudah standar dan diakui bahkan oleh dunia internasional, seperti 'Arabiyah li alNāsbi'in, ${ }^{45}$ 'Arabìah bayn Yadayk, ${ }^{46}$ dan lain-lain.

\footnotetext{
${ }_{44}$ Dalam konteks pembelajaran bahasa Arab di Indonesia, nampaknya kementerian agama kurang menganggap penting peranan buku ajar, sehingga sampai saat ini tidak ditemukan buku ajar bahasa Arab yang dikeluarkan oleh tim penyusun buku yang dibentuk oleh kementerian Agama. Kementerian Agama hanya menyusun kurikulum sebagai acuan dan rambu-rambu dalam penyusunan buku. Karena demikian, buku ajar yang beredar di pasaran sangat jauh dari kata layak dan bukan merupakan satu kesatuan yang utuh. Hal ini dapat disimpulkan dengan membandingkan buku ajar yang dipakai di lembaga pendidikan formal dengan buku ajar al-'Arabiyah li al-Näshi'in yang dikeluarkan oleh kerajaan Arab Saudi.

${ }^{45}$ Buku al-'Arabìah li al-Näshi'in merupakan buku yang dipersiapkan oleh kerajaan Arab Saudi melalui kementerian pendidikan dengan bekerja sama dengan Universitas al-Riyāḍ. Buku yang terdiri dari enam jilid ini diperuntukkan peserta didik non-Arab usia 11 sampai 17 tahun. Buku ini disusun oleh tim penulis yang terdiri dari Mahmud Isma'il Shiniy, Nashif Mushthafa Abdul Aziz dan Mukhtar Thahir Hasin. Dari kata pengantar, petunjuk penggunaan dan isi buku nampak sekali bahwa buku ini ditulis secara serius dan teliti dengan memperhatikan tahapan keterampilan bahasa yang jelas dan terukur, baik dari sisi qawaid, mufradät dan yang lain. Buku ini terdiri dari enam jilid dan masing-masing jilid terdiri dari dua paket buku, yaitu Kitab al-Tilmidh dan kitab al-Mu'allim. Keseriusan penyusunan buku ini
} 
Setelah bi'ah 'Arabiyah terbentuk dan guru yang menjadi fasilitator pembelajaran sudah memenuhi kualifikasi yang diharapkan, serta buku ajar yang pergunakan sudah terstandarisasi dengan baik, selanjutnya yang perlu diupayakan adalah bagaimana memastikan semangat belajar dan konsistensi peserta didik dalam mencapai tujuan yang telah ditetapkan tetap bergelora dan terus membara. Dalam konteks lembaga pendidikan pesantren hal ini sangat mudah untuk diupayakan, karena sistem ta'zir (punishmant) yang diterapkan di lembaga pondok pesantren merupakan sesuatu yang diterima oleh masayarakat secara integral dengan pesantren dan tidak dapat dipisahkan dari pesantren. Hal berbeda terjadi dalam konteks lembaga pendidikan formal. Kasus guru menjadi tersangka dan bahkan menjadi seorang terpidana gara-gara memberi sanksi kepada peserta didik yang bandel merupakan fenomena yang nyata terjadi di negeri ini, sehingga $t a$ 'zi $r$ yang fungsi utamanya adalah memaksa peserta didik untuk belajar secara maksimal harus diberupakan bentuk lain.

Peserta didik yang memilih jalur pendidikan formal pasti memiliki tujuan formal, yaitu dapat lulus ujian nasional dan mendapatkan sertifikat ijazah yang dapat dipergunakan untuk mencari pekerjaan atau melanjutkan pendidikan ke jenjang yang lebih tinggi. Orientasi formalitas inilah yang harus dimainkan secara maksimal oleh penentu kebijakan untuk memaksa para peserta didik dan bahkan orang tua agar peserta didik belajar secara maksimal materi bahasa Arab. Hal ini dapat dilakukan dengan cara menjadikan penguasaan materi bahasa Arab dalam tingkatan tertentu yang rasional sebagai persyaratan untuk kelulusan ujian, sebagaimana materi pelajaran matematika, bahasa Indonesia dan lain-lain. Dengan cara seperti ini pasti orang tua segala upaya untuk menjadikan putra-putrinya memenuhi standar ketuntasan minimal untuk materi pelajaran bahasa Arab dengan cara memanggil

juga terlihat dari tersedianya CD pembelajaran. Lebih lanjut lihat Maḥmūd Ismā̄̄l Șinnìy dkk, al-'Arabìyah li al-Nāshi'in (Riyad: Idārat al-Kutub al-Madrasīyah, t.th.).

${ }^{46}$ Buku al-'Arabiyah bayn Yadayk merupakan buku bahasa Arab yang terdiri dari tiga jilid. Buku yang disiapkan untuk peserta didik non-Arab ini disusun oleh tim penyusun yang terdiri dari 'Abd al-Raḥmān b. Ibrāhīm al-Fawzān, Mukhtār Ṭāhir Hāsin dan Muhammad 'Abd al-Khāliq Muhammad Fadhl. Buku ini disusun sangat serius karena tahapan perkembangan keterampilan bahasa yang ingin dicapai dari berbagai dimensinya diperhitungkan secara matang dan terukur sampai pada kalkulasi waktu yang dibutuhkan untuk mempelajari buku ini. Buku ini terdiri dari dua paket, yaitu kitab al-Ṭāalib dan kitab al-Mu'allim. Lihat 'Abd al-Raḥmān b. Ibrāhīm al-Fawzān dkk, al-'A rabīyah bayn Yadayk (Riyad: al-Maktabah al-Ra’̄is, 2005). 
guru privat atau mengirim ke lembaga bimbingan belajar, sebagaimana hal ini dilakukan terhadap materi ujian nasional yang lain.

\section{Penutup}

Semua bahasa memiliki karakter yang sama. Penguasaannya tergantung pada sejauh mana bahasa itu dibiasakan, sehingga tugas utama dari penentu kebijakan adalah bagaimana "memaksa" peserta didik untuk "terbiasa" berbahasa. Kesuksesan Pondok Pesantren Assunniyyah Kencong Jember dalam pembelajaran bahasa Arab lebih disebabkan karena mereka mampu menghadirkan bi'ab 'Arabiyah di lingkungan pesantren, meskipun menggunakan ta'zir sebagai salah satu pendekatannya. Lembaga pendidikan formal kurang sukses, atau bahkan gagal dalam pembelajaran bahasa Arab lebih disebabkan karena mereka gagal menghadirkan bìah 'Arabìyah di lingkungan mereka. Ada banyak hal yang perlu dibenahi dalam konteks mendesain pembelajaran bahasa Arab di lingkungan pendidikan formal, baik terkait dengan penciptaan lingkungan, kualifikasi guru dan standarisasi buku ajar sebagai sumber belajar, atau terkait dengan posisi bahasa Arab sebagai materi yang cukup menentukan kelulusan peserta didik. Hal ini dapat direalisasikan dengan baik ketika penentu kebijakan memiliki visi yang jelas terhadap materi pelajaran bahasa Arab.

\section{Daftar Rujukan}

Afghānī (al), Sa'îd b. Muhammad b. Aḥmad. al-Mujī̌ fi Qawä'id alLughah al-'Arabìyah. Beirut: Dār al-Fikr, 2003.

Ahmad Muhammad Nasih (Guru Tugas Pondok Pesantren Assunniyyah Kencong Jember). Wawancara. Jember 17 Juli 2017.

'Alī, Muhammad Ma'șūm b. al-Amthilah al-Tașiffyah. Surabaya: Maṭba'ah Sālim Nabhān, t.th.

'Aqil, 'Abd Allah b. Sbarḅ Ibn 'Aqül, Vol. 1. Beirut: Dār al-Fikr, t.th.

'Aqil, Ibn. Sharḅ Ibn 'Aqül 'alā Alfiyat ibn Mälik, Vol. 2. Kairo: Dar alTurāth, 1980.

Bäjurī (al). Fatḥ Rabb al-Barìyah 'alā al-Durrah al-Babìyah: Sharh Imrịtī. Surabaya: Maktabah Imaratullah, t.th.

Darsono dan Ibrahim, T. Fasib Berbahasa Arab Untuk Kelas IX Madrasah Tsanawiyah. Solo: PT Tiga Serangkai, 2013.

Darsono dan Ibrahim, T. Fasib Berbahasa Arab untuk Kelas VII Madrasah Tsanawiyah. Solo: PT Tiga Serangkai, 2014. 
Darsono dan Ibrahim, T. Fasib Berbahasa Arab Untuk Kelas VIII Madrasah Tsanawiyah. Solo: PT Tiga Serangkai, 2015.

Fahrurrozi, Aziz. "Pembelajaran Bahasa Arab: Problematika dan Solusinya", Arabiyat. Jurnal Pendidikan Babasa Arab dan Kebahasaaraban, Vol. 1, No. 2, 2014.

Fawzān (al), 'Abd al-Raḥmān b. Ibrāhīm dkk. al-'Arabìyah bayn Yadayk. Riyad: al-Maktabah al-Ra'̄s, 2005.

Ghulayaynī (al), Muhammad b. Muhammad Sālim. Jāmi‘ al-Durūs al'A rabiyah, Vol. 2 (Beirut: al-Maktabah al-'Așrīyah, 1993.

Hidayat, Saepul. Belajar Efektif Bahasa Arab Untuk Madrasah Aliyah Kelas XII. Jakarta Timur: PT Intermedia Ciptanusantara, t.th.

Kementerian Agama Republik Indonesia. Durus al-Lughab al'Arabiyyab: Buku Siswa Bahasa Arab Pendekatan Saintifik Kurikulum 2013 Kelas X. Jakarta: Kementerian Agama Republik Indonesia, 2014.

-----. Durūs al-Lughah al-'Arabiyah: Buku Siswa Bahasa Arab Pendekatan Saintifik Kurikulum 2013 Kelas XI. Jakarta: Kementerian Agama Republik Indonesia, 2015.

Kurniawan, Ahmad Faiz (Pengurus Pondok Pesantren Assunniyyah Kencong Jember). Wawancara. Jember 23 April 2017.

Ma'arif, M. Syamsul. "Perbandingan Kualitas Buku Teks Bahasa Arab Tingkat Madrasah Tsanawiyah", Jurnal Pendidikan Islam, Vol. 4, No. 1, Juni 2015.

Mahyudin, Erta. "Model Pembelajaran Diskoveri sebagai Strategi Pembelajaran Bahasa Arab", Arabiyat: Jurnal Pendidikan Bahasa Arab dan Kebabasaaraban, Vol. 1, No. 2, 2014.

Nafisah, Aliyatin. "Model dan Problematika Pembelajaran Bahasa Arab di SMA Islam Keling Jepara", Cendekia, Vol. 10, No. 1, Juni 2012.

Nasih, Ahmad Muhammad (Guru Tugas dari Pondok Pesantren Assunniyyah Kencong Jember). Wawancara. Jember 17 Juli 2017.

Naysābūrī (al), Abū 'Abd Allah al-Ḥākim. al-Mustadrak 'alā al-Ṣaḩịhayn, Vol. 4. Beirut: Dār al-Kutub al-'Ilmìyah, 1990.

Qari (al), Abū al-Ḥasan Nūr al-Dīn al-Mala al-Ḥarawī. Mirqat alMafätih: Sharḥ Mishkaàt al-Masābih, Vol. 3. Beirut: Dār al-Fikr, 2002. Șinnìy, Maḥmūd Ismā̄̄il dkk. al-'Arabìyah li al-Nāshi'inn. Riyad: Idārat alKutub al-Madrasiyah, t.th.

Sijistānī (al), Abū Dāwud. Sunan Abì Dāwnd. Beirut: al-Maktabah al'Așrīyah, t.th. 
Syaddad, Anwar (Ustaz Pembina Persiapan Lomba Pondok Pesantren Assunniyyah Kencong Jember). Wawancara. Jember 25 Februari 2017.

Ṭaqtuqī (al), Ibn. al-Fakhr fì al-Adab al-Sultānīyah wa al-Duwal alIslämìah. Beirut: Dār al-Qalam al-'Arabī, 1997.

Tamam, Asep M. "Program Penyiapan dan Pembinaan Guru Bahasa Arab Profesional di Indonesia", Arabiyat: Jurnal Pendidikan Babasa Arab dan Kebahasaaraban, Vol. 1, No. 1, 2014.

Ulyan, Ahmad Fuad. al-Mahārat al-Lughawīyah. Riyad: Dār al-Salām, 1992.

Wahab, Muhbib Abdul. "Pembelajaran Bahasa Arab di Era Posmetode", Arabiyat: Jurnal Pendidikan Bahasa Arab dan Kebahasaaraban, Vol. 2, No. 1, 2015.

Zaini, Ahmad (Ustaz Pondok Pesantren Assunniyyah Kencong Jember), Wawancara, Jember 23 Februari 2017.

----. W awancara. Jember 21 Januari 2017.

Zarnujī (al), Burhān al-Islām. Ta'lìm al-Muta'allim Tarìq al-Ta'allum. Khartoum: al-Dār al-Sūdānīyah li al-Kutub, 2004.

Zuhair, Agus H. Baha'uddin (Mudir 'Ám Pondok Pesantren Assunniyyah Kencong Jember). Wawancara. Jember 26 Februari 2017. 